\title{
Is teacher certification an effective tool for developing countries?
}

\section{Increasing teacher certification in developing countries is widely believed to improve student performance; yet the evidence suggests otherwise}

Keywords: education, teacher training, teacher certification, qualified teachers, contract teachers

\section{ELEVATOR PITCH}

Teachers are perhaps the most important determinant of education quality. But what makes a teacher effective? Developing countries expend substantial resources on certifying teachers and retaining those who become certified; moreover, policymakers and aid donors prioritize increasing the prevalence of certified teachers. Yet there is little evidence that certification improves student outcomes. In fact, augmenting a school's teaching corps with contract teachers hired outside the civil service and without formal qualifications may be more effective in boosting student performance.

\section{KEY FINDINGS}

\section{Pros}

( Improving teacher quality is likely to have large positive effects on student performance in developing countries, given low levels of student learning, school resources, and institutional capacity.

๑ Expanding teacher certification in developing countries would raise teacher qualifications from a low base, particularly in the poorest regions.

๑ Strong support for expanding the certified teaching corps exists among both policymakers and aid donors.

() There is great potential to strengthen the link between the content of certification programs and improvements in teacher quality.

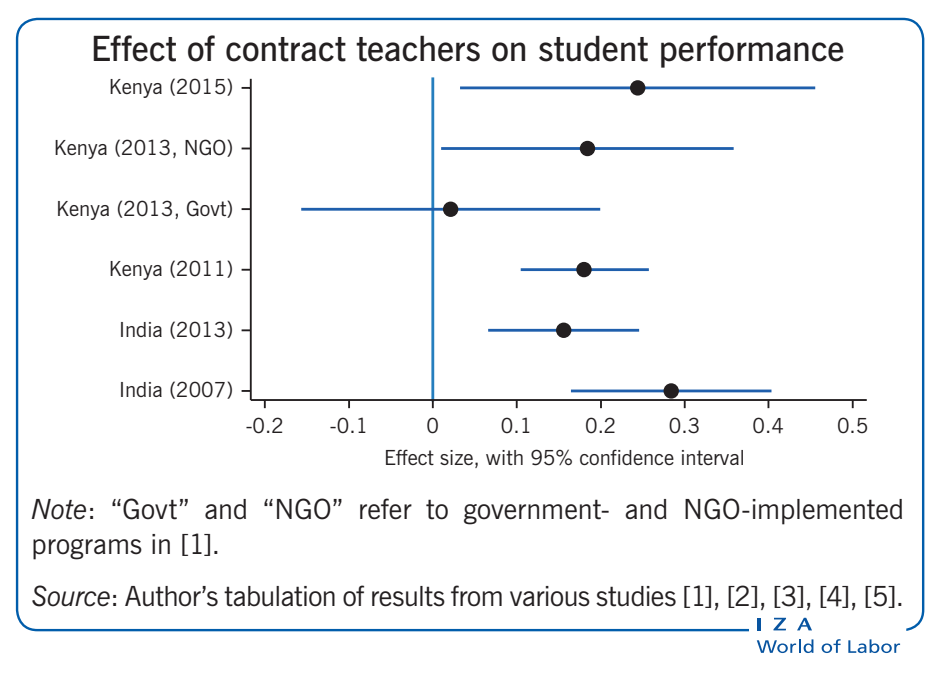

\section{Cons}

- In its present form, teacher certification is not associated with better student performance.

- Augmenting a school's teaching corps with contract teachers, who are often uncertified, can improve student performance.

- Certified teacher salaries are several times those of uncertified teachers in many countries.

- Given the lack of association between certification and student learning, the opportunity cost of certification programs appears high.

\section{AUTHOR'S MAIN MESSAGE}

Increasing the presence of certified teachers from their low base seems an obvious way to improve education quality in developing countries. Yet the most rigorous research finds no association between teacher certification and student performance. By contrast, contract teachers, who are often uncertified, have demonstrated a capacity to raise learning outcomes when added to a school's teaching corps. Expansions of teacher certification should thus be accompanied by efforts to strengthen the link between certification programs and improvements in teacher quality. 


\section{MOTIVATION}

The quality of an individual's education is principally determined by the quality of teaching he or she receives. But what determines the effectiveness of the teacher? Formal teacher training provides an obvious starting point, and in developing countries considerable resources are spent on certifying teachers and on retaining those who are certified. Certification usually occurs as a result of several years of training at public universities, and certified teachers often earn several times more than their uncertified counterparts.

Similarly, policymakers and aid agencies are increasingly prioritizing the importance and prevalence of certified teachers. For example, the United Nations (UN) Sustainable Development Goals (SDGs), adopted in 2016, include a target to "substantially increase the supply of qualified [certified] teachers." Yet despite these efforts, rigorous studies of how teacher qualifications influence student performance in developing countries have emerged only recently.

While increasing the presence of certified teachers from their low base seems an obvious way to improve education quality in developing countries, the evidence in favor of certified teachers, however, is strikingly thin. There is an opportunity cost in certifying teachers, in terms of program tuition and subsequent increased salary, which should be weighed up carefully against the potential benefits of contracting.

\section{Teacher quality and teacher qualifications}

Teacher quality refers to a teacher's ability to promote student development. Researchers often measure teacher quality by estimating a teacher's ability to increase student test scores relative to a baseline score, such as in value-added models.

Qualified or certified teachers are those holding a credential established by an education system, often requiring completion of a multi-year training program in a college of education.

Well-trained teachers are those whose training has increased their quality beyond what it would have been otherwise and who meet a minimum standard of quality. Qualified/ certified teachers become well-trained only if their certification program is of sufficient quality. Increasing the stock of qualified teachers will therefore not necessarily meet the goal of providing all students with a well-trained teacher.

\section{DISCUSSION OF PROS AND CONS}

\section{Teachers in developing countries}

Many teachers in developing countries lack formal training. Around one in four primary school teachers, and nearly one in two secondary school teachers, are uncertified in lowincome countries. Rates in sub-Saharan Africa are similar (Figure 1). By comparison, 83\% of secondary school teachers are certified in the US.

School enrollment has grown considerably in developing countries over the past 25 years. Developing country governments and international financial institutions increased access to education through school construction, tuition elimination, budgetary support, and other policies. Yet the supply of available teachers, particularly those with formal 
Figure 1. A large proportion of teachers in the developing world are uncertified

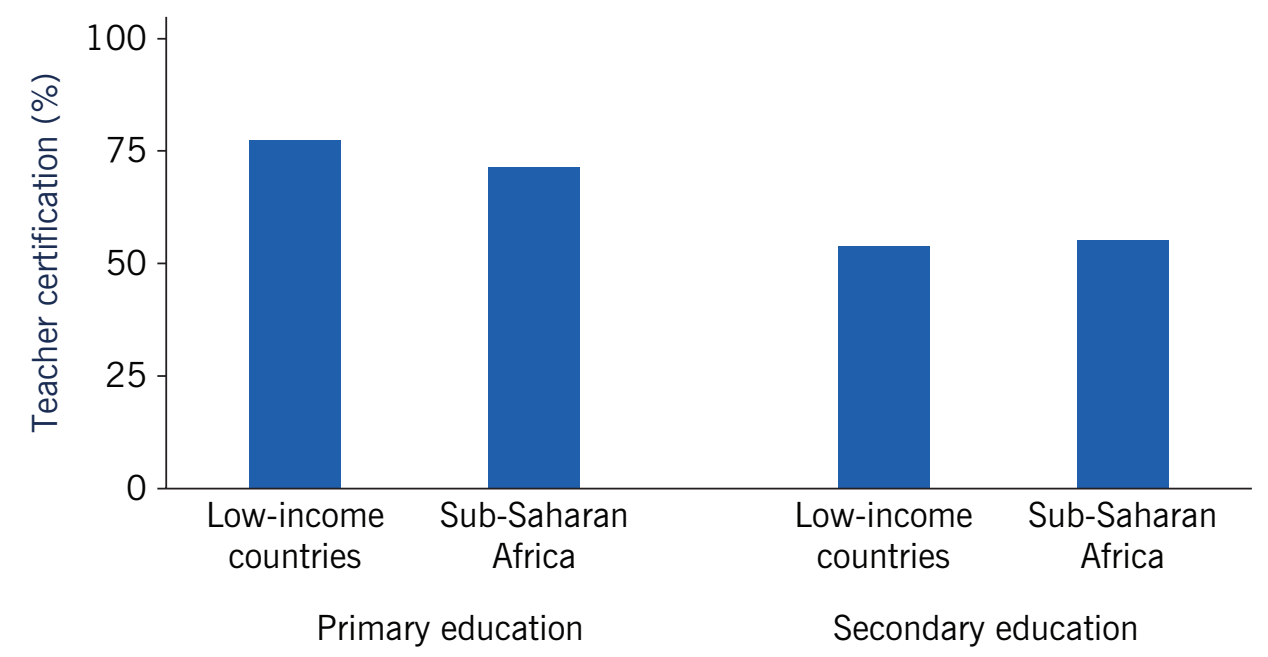

Source: UNESCO Institute for Statistics, 2013 data. Online at: http://www.uis.unesco.org/DataCentre/Pages/ BrowseEducation.aspx

qualifications, did not keep pace with expanding student enrollment. To achieve universal primary education, UNESCO projected that 1.7 million additional teachers would be needed between 2010 and 2015, with $60 \%$ of this increase required alone in sub-Saharan Africa. Although this figure is staggering, it is arguably conservative, as it would merely maintain existing pupil-teacher ratios at their already high levels, which is currently 42 primary school pupils per teacher in low-income countries, compared with only 14 pupils per teacher in developed countries.

Teacher salaries are the single largest component of school budgets, constituting 70-90\% of school expenditures in developing countries. Salaries for certified teachers represent approximately two-thirds of this amount [6]. Civil service teachers, who are usually certified, earn between 1.2 and five times the salaries of contract teachers, who are often uncertified, across several countries for which there is data (Figure 2). These expenditures exclude the training costs incurred during certification itself, which often takes place over several years at public universities.

Belief in teacher certification as a key component of education quality is widespread among policymakers, aid donors, and education advocates. The Global Campaign for Education, a coalition of civil society groups, wrote in a recent report that "a fundamental reason for [the] gap in quality education is the severe lack of well-trained, well-supported teachers ... If we are genuinely serious about fulfilling the right to education for all ... then the only solution is to ensure that every student has a well-trained teacher." The UN SDGs include a target to "substantially increase the supply of qualified [certified] teachers" by 2030.

The prominent place occupied by certified teachers in the budgets and policy priorities of developing country education systems is understandable. An emerging consensus among education researchers considers teacher quality to be the single most important input for student success. Teachers are likely to play especially important roles in developing countries, where inadequate school infrastructure and other constraints are more severe. Increasing the share of certified teachers holds the promise of strengthening the skills and 
Figure 2. Civil service teachers earn considerably more than contract teachers

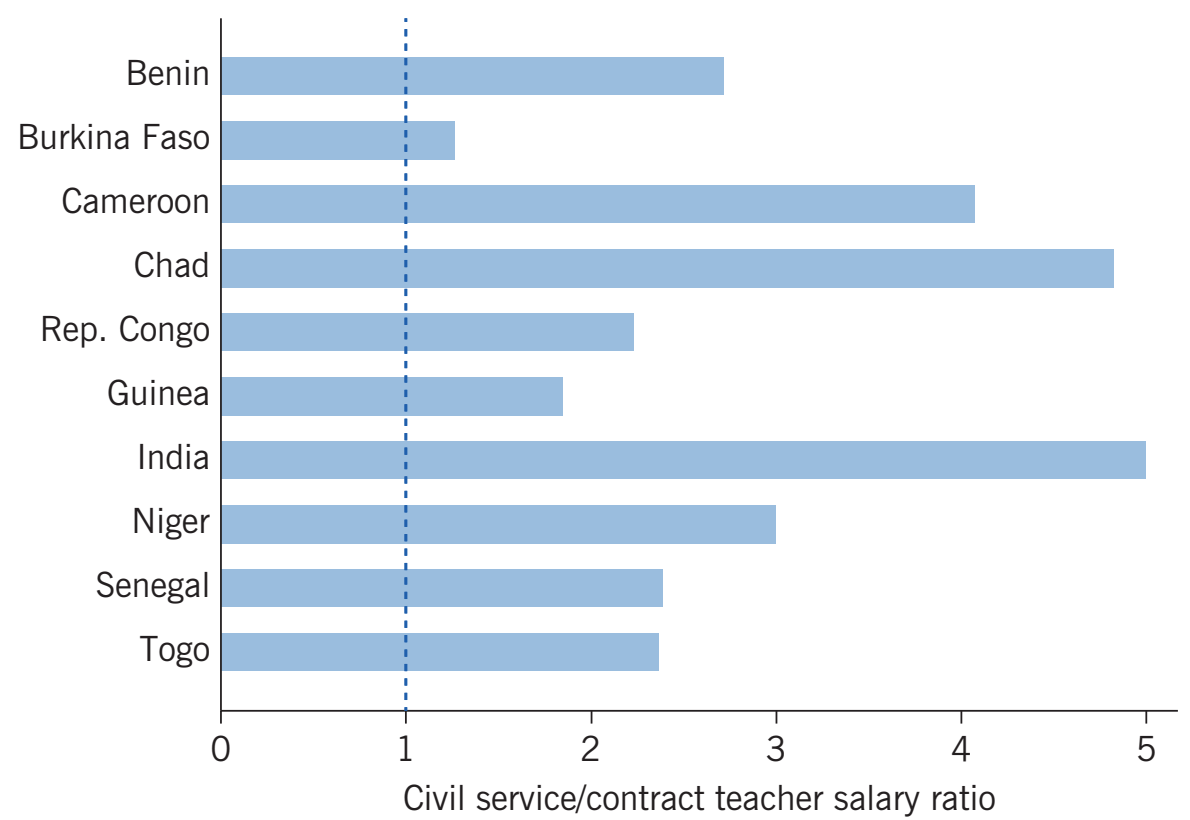

Notes: A ratio of 1 indicates that civil service and contract teachers have equal salaries. A ratio greater than 1 indicates that civil service teachers earn more than contract teachers.

Source: Muralidharan, K., and V. Sundararaman, Contract Teachers: Experimental Evidence from India. NBER Working Paper 19440, September 2013 [5]; Bourdon, J., M. Frölich, and K. Michaelowa, "Teacher shortages, teacher contracts and their effect on education in Africa." Journal of the Royal Statistical Society Series A 173:1 (2010): 93-116 [6]. I Z A

professionalism of the teaching corps. The additional cost might yield long-term social returns that would be sufficient to justify the expense.

Even if the consensus view on the importance of teacher quality holds true, however, it does not necessarily follow that education policy should focus on teacher qualifications. The terms teacher quality, qualified teacher, certified teacher, and well-trained teacher are often used interchangeably, but they have important differences. Fundamentally, the skills acquired in a formal teacher-training program may not be the same skills that matter most for student performance. Many pre-service teacher-training programs focus on pedagogical theory, with less emphasis on the classroom skills needed to improve student performance. Ultimately the question is empirical. Yet rigorous studies of how teacher qualifications influence student performance have emerged only recently.

\section{Evidence on teacher certification}

\section{Training and certification}

Disentangling the effect of certification from other characteristics is difficult, because certified teachers differ from uncertified teachers along many dimensions. Certified teachers usually earn substantially higher salaries than their uncertified counterparts; they are also generally more experienced and have union representation, among other differences. Moreover, certified teachers are not randomly allocated among schools. Their greater bargaining power, and the perception that they are higher quality than uncertified teachers, allow them to secure posts in the most favorable schools. And even when the characteristics of teachers (e.g. experience, salary, union representation) and schools are 
observed in the data, unobserved differences between certified and uncertified teachers, such as ability or motivation, would be likely to confound comparisons between them.

Using randomized control trials (RCTs), or natural experiments, is a way of addressing these challenges, as they provide randomness in treatment and thereby reduce the risk of selection bias. The use of RCTs has increased significantly in recent years. Several systematic reviews, or "meta-studies," of education interventions in developing countries have attempted to draw lessons from this research, limiting attention to studies with the strongest research designs. Most studies measure effectiveness according to students' standardized test scores in mathematics and language, or other measures of cognitive skills. Teacher training rates highly in these reviews as a means of improving student performance. However, this conclusion rests largely on results from specific training undertaken during the course of a teaching post (i.e. "in-service" training), and is typically quite short and narrowly targeted to particular features of a curriculum, such as the introduction of a new technology. Evidence on the "pre-service," multi-year training that characterizes the preparation for teacher certification in most countries is more difficult to find.

Research from the US using large-scale, longitudinal data is virtually unanimous in its failure to find an association between teacher certification and student performance. One might expect certification to play a more important role in developing countries, however. In developed countries, a master's degree usually distinguishes certified and uncertified teachers. In contrast, in developing countries, certification is typically earned through an undergraduate program. When the difference between certified and uncertified teachers is equivalent to that between a university graduate and someone with at most a high school diploma, classroom performance might differ greatly.

Nonetheless, research from developing countries largely echoes the findings from wealthier countries. A study of rural primary schools in China, using a similar methodology as the US studies, found that college attendance was not associated with a teacher's effectiveness [7]. A program in the Gambia that paid a $30-40 \%$ bonus to teach in remote primary schools, succeeded in increasing the proportion of certified teachers [8]. However, comparing students in schools near the arbitrarily assigned distance cut-off for this bonus revealed no differences in test scores based on the presence of certified teachers [9]. An experiment in Chile provided two years of professional development to pre-primary teachers. This training increased pedagogical quality, but failed to improve students' cognitive skills [10]. Another experiment in Indonesia encouraged teachers to become certified in exchange for a doubling of their salary [11]. Again, even though the presence of certified teachers increased, the authors found no effect of the program on student learning.

\section{Contract teachers}

A related body of research looks at differences between civil service and contract teachers. Civil service status and certification are not synonymous; both certified and uncertified teachers are found among civil service and contract teachers. Nonetheless, in most developing countries, the correlation between certification and civil service status is sufficiently strong to make for a reasonable proxy. Similar to certified teachers, civil service teachers receive higher pay, are more often represented by a union and enjoy greater employment protection and job security than their counterparts hired on shortterm contracts. But are civil service teachers also more effective than contract teachers? 
A longitudinal study in India found that "despite being paid just a third of the salary of regular teachers with similar observed characteristics, contract teachers produce higher student learning" [12]. Another study that relied on matched comparisons between contract teachers with observationally similar civil servants in Mali, Togo, and Niger, found mixed results, with positive, null, and negative effects on student test scores in those countries, respectively [6].

Although these studies make best use of the available data, they are nonetheless hampered by potential biases due to unobservable characteristics between teacher types previously referred to, as well as by differences in management and resources between schools that employ contract teachers and those that do not. Other researchers have thus attempted to overcome this concern by experimentally manipulating the presence of contract teachers in schools.

In India, a program contracted young women without formal teacher training from the local community to provide remedial education to primary school children who were lagging behind [1]. Schools were randomly selected for students to receive the program in grade 3 or grade 4; the students in grades not receiving the program within these schools became the control group. The classes taught by these contract teachers were not part of the standard curriculum, though they did take place during school hours. The program increased test scores by 0.28 standard deviations, which is a sizable effect.

Although these results may conflate the impact of contract teachers with that of the remedial program itself, it is nonetheless notable that untrained teachers delivered the program successfully. As the first RCT on contract teachers to report results, this study represents an important "proof of concept" for the potential gains from hiring untrained teachers.

Another experiment in Kenya randomly selected schools to receive an additional contract teacher in the first grade [3]. Schools used the extra teacher to reduce class sizes. As a result, test scores improved by 0.18 standard deviations for students taught by a contract teacher. As with the Indian experiment, these gains might conflate the contract teacher effect with concurrent changes induced by the experiment, in this case the reduction in class size. Additionally, contract status may exert an independent effect on teacher performance. For instance, contract teachers may work harder than they otherwise would, in an attempt to renew the contract or secure a civil service job. Contract teachers may also be more likely to come from the local area of a school, thus giving them a stronger connection to their students, or may have other distinct characteristics that contribute to their performance. Again, however, it is notable that contract teachers performed significantly better than their civil service counterparts, when conventional wisdom suggests the opposite.

Yet another experiment in a different set of Kenyan primary schools introduced a similar intervention, randomly choosing some schools to receive an additional contract teacher [4]. Again, researchers found a 0.18 standard deviation increase in test scores, with similar caveats to the interpretation. However, this second Kenyan study went a step further by running a parallel intervention that was identical, except that it was implemented by the government, rather than a non-governmental organization (NGO). Remarkably, the contract teacher program operated by the government failed to produce any test score gains; students scored the same, on average, regardless of whether they had a civil service or contract teacher. The authors interpreted their results as evidence of the importance 
of implementation of the contract teacher program in the intervention's success. The scale, implementation capacity, and institutional constraints under which a program operates are decisive for its ultimate impact. In the case of contract teachers, the study finds that contract teachers in the government-implemented program were more likely to identify with the teachers' union. The authors conjectured that "while a small number of contract teachers can be employed at wages far below civil service levels, a large cohort of contract teachers becomes politically potent and able to demand civil service protections" [4]. Teachers hired by governments may expect a different set of benefits and working conditions from those in an NGO program, with potentially important consequences for their job performance.

The failure of government initiatives to reap gains from contract teachers is not universal, however. In the Indian state of Andhra Pradesh, half of a sample of 200 schools was randomly selected to receive an additional contract teacher, similar to the programs described above. This program was notable in that it was implemented by the government using the same policy (other than randomization) to hire contract teachers as in normal operations. This design mitigated many of the earlier concerns about NGO implementation and scale-up, such as the relative ease of assuring quality in a small-scale program, the superior implementation capacity of NGOs, or their relative freedom from political constraints. As a result, students of contract teachers scored 0.16 standard deviations better than students of civil service teachers [5].

As with the other experiments, this result may confound the contract teacher effect with class-size reduction. The study partially addresses this concern by noting that because pre-existing class sizes varied, reductions in pupil-teacher ratios were not uniform across schools, and the variation in these reductions was randomly determined. Comparing the response of contract teachers to class-size reductions with that of civil service teachers in control schools, the authors find that contract teachers take better advantage of smaller classes. Although their method must ultimately rely on non-experimental classsize variation in control schools to make this comparison, the researchers nonetheless go further than previous studies in substantiating the direct benefits of contract teachers.

The illustration on page 1 summarizes the evidence from RCTs of contract teachers, with $95 \%$ confidence intervals around the corresponding point estimates, which implies a reasonably accurate representation. The figure reports one additional study in Kenya not mentioned above. In that experiment, contract teachers had to meet minimum qualifications for eligibility, making the certification distinction between teacher contract types less clear [2]. Contract teachers outperformed their civil service counterparts, which is consistent with other studies cited in this article, though with similar caveats about the confounding influence of class-size reductions.

\section{LIMITATIONS AND GAPS}

Despite the experimental methods used in the contract teacher studies referred to in this article, they each have limitations in their ability to quantify the impact of teacher certification on student performance. The bundling of contract teachers with class-size reductions, the imperfect relationship between civil service status and certification, the incentives inherent to different contract types, and the greater likelihood that contract teachers are from the school's local area, have all previously been mentioned as weaknesses in existing research designs. The inability to distinguish these characteristics from 
certification status renders studies of contract teachers a flawed vehicle for understanding the role of certification in student performance. Although in principle it might be possible to address these limitations through clever design of future research (for instance, by randomly allocating local and non-local contract teachers across schools), it is unlikely that a single study of contract teachers could address all confounders simultaneously.

More fundamentally, no study exists that randomly swaps a student's uncertified teacher with a certified one, leaving all else unchanged. Such a study could be the ideal way of quantifying the effect of teacher certification on student performance, which is the motivating question of this review. It would still be incomplete, however, because it would only address how differences in certification status among the existing stock of teachers affects performance. The effect of providing certification to a new teacher would be left unanswered.

A related, but different type of study might ask how providing certification to a presently uncertified teacher would affect his/her teaching effectiveness. Such a study would address more directly the policy question behind the UN SDG of increasing the presence of certified teachers. It might be conducted by (randomly) encouraging uncertified teachers, or students deciding on a post-secondary career path, to seek certification, through information campaigns, tuition reductions, or other incentives, and comparing them with a control group not offered these inducements. The experimental studies from Chile and Indonesia cited earlier approximate this ideal, but imperfectly. Generalizability from the small scale of the Chilean study, which included just 64 schools, is unclear [10]. The certification program in the Indonesian study was limited to submission of a teaching portfolio and two weeks of training, making it far more limited in scope than typical multiyear pre-service certification programs. Additionally, the bundling of certification with a salary increase of $100 \%$ makes it difficult to attribute the (null) effects of the program to certification itself [11].

Also absent from the evidence on certification is whether the content, duration, or other design features of pre-service training programs matter. Nor has the existing research focused on non-cognitive skills, which may equal the importance of cognitive skills for adult outcomes. And because most existing evidence is from primary schools, only little is known about the role of certification among secondary school teachers, for whom detailed subject knowledge is likely more important. Thus, much fruitful research remains to be done.

\section{SUMMARY AND POLICY ADVICE}

Increasing the presence of certified teachers from their low base seems an obvious way to improve education quality in developing countries. The evidence in favor of certified teachers is strikingly thin, however. The most rigorous research finds no association between teacher certification and student performance. Comparisons between contract teachers, who are often uncertified, and their civil service counterparts consistently favor contract teachers, or at least find them no less effective. This evidence should give policymakers pause for thought when considering whether to expand existing teacher certification programs. Such programs hold the promise of improving teacher performance, or of distinguishing the most capable teachers from others, but have not consistently demonstrated either function in their current form. Although providing certification to an uncertified teacher is 
unlikely to reduce his/her quality, the opportunity cost of certification, in terms of program tuition and subsequently increased salary, is substantial.

Gaps remain in the literature, particularly on the content of teacher training, its effect on students' non-cognitive skills, and its importance in secondary education. Therefore, addressing these gaps would help policymakers align efforts to expand teacher certification with increases in teacher quality.

\section{Acknowledgments}

The author thanks two anonymous referees and the IZA World of Labor editors for many helpful suggestions on earlier drafts. Roberta Nilson also provided excellent research assistance.

\section{Competing interests}

The IZA World of Labor project is committed to the IZA Guiding Principles of Research Integrity.

The author declares to have observed these principles.

(c) Todd Pugatch 


\section{REFERENCES}

\section{Further reading}

Glewwe, P. W., E. A. Hanushek, S. D. Humpage, and R. Ravina. School Resources and Educational Outcomes in Developing Countries: A Review of the Literature from 1990 to 2010. NBER Working Paper 17554, 2011.

McEwan, P. J. "Improving learning in primary schools of developing countries: A meta-analysis of randomized experiments." Review of Educational Research 85:3 (2015): 353-394.

Murnane, R. J., and A. J. Ganimian. Improving Educational Outcomes in Developing Countries: Lessons from Rigorous Evaluations. NBER Working Paper 20284, 2014.

\section{Key references}

[1] Banerjee, A. V., S. Cole, E. Duflo, and L. Linden, "Remedying education: Evidence from two randomized experiments in India." Quarterly Journal of Economics 122:3 (2007): 1235-1264.

[2] Duflo, E., P. Dupas, and M. Kremer. "School governance, teacher incentives, and pupil-teacher ratios: Experimental evidence from Kenyan primary schools." Journal of Public Economics 123 (2015): 92-110.

[3] Duflo, E., P. Dupas, and M. Kremer. "Peer effects, teacher incentives, and the impact of tracking: Evidence from a randomized evaluation in Kenya." American Economic Review 101:5 (2011): 1739-1774.

[4] Bold, T., M. Kimenyi, G. Mwabu, A. Ng'ang'a, and J. Sandefur. Scaling Up What Works: Experimental Evidence on External Validity in Kenyan Education. Center for Global Development Working Paper No. 321, 2013.

[5] Muralidharan, K., and V. Sundararaman. Contract Teachers: Experimental Evidence from India. NBER Working Paper 19440, September 2013.

[6] Bourdon, J., M. Frölich, and K. Michaelowa, "Teacher shortages, teacher contracts and their effect on education in Africa." Journal of the Royal Statistical Society: Series A 173:1 (2010): 93-116.

[7] Chu, J. H., P. Loyalka, J. Chu, Q. Qu, Y. Shi, and G. Li, "The impact of teacher credentials on student achievement in China." China Economic Review 36 (2015): 14-24.

[8] Pugatch, T., and E. Schroeder. "Incentives for teacher relocation: Evidence from the Gambian hardship allowance.” Economics of Education Review 41 (2014): 120-136.

[9] Pugatch, T., and E. Schroeder. Teacher Pay and Student Performance: Evidence from the Gambian Hardship Allowance. IZA Discussion Paper No. 8621, November 2014.

[10] Yoshikawa, H., D. Leyva, C. E. Snow, E. Treviño, M. Clara, C. Weiland, C. J. Gomez, L. Moreno, A. Rolla, N. D'Sa, and M. C. Arbour. "Experimental impacts of a teacher professional development program in Chile on preschool classroom quality and child outcomes." Developmental Psychology 51:3 (2015): 309-322.

[11] de Ree, J., K. Muralidharan, M. Pradhan, and H. Rogers. Double for Nothing? Experimental Evidence on the Impact of an Unconditional Teacher Salary Increase on Student Performance in Indonesia. NBER Working Paper 21806, December 2015.

[12] Atherton, P., and G. Kingdon. The Relative Effectiveness and Costs of Contract and Regular Teachers in India. CAES Working Paper No. 15, 2010.

\section{Online extras}

The full reference list for this article is available from:

http://wol.iza.org/articles/is-teacher-certification-an-effective-tool-for-developing-countries

View the evidence map for this article:

http://wol.iza.org/articles/is-teacher-certification-an-effective-tool-for-developing-countries/map 